\title{
What Factors Determine Membership to Farmer Groups in Uganda? Evidence from the Uganda Census of Agriculture 2008/9
}

\author{
A. Adong ${ }^{1}$, F. Mwaura ${ }^{1} \&$ G. Okoboi ${ }^{1}$ \\ ${ }^{1}$ Sectoral Department, Economic Policy Research Centre, Kampala, Uganda \\ Correspondence: A. Adong, Sectoral Department, Economic Policy Research Centre, Kampala, Uganda. Tel: \\ 256-414-541-023. E-mail: aadong@eprc.or.ug or annetteadong@yahoo.com
}

$\begin{array}{lc}\text { Received: February 15, } 2013 & \text { Accepted: March 15, } 2013 \quad \text { Online Published: March 20, } 2013 \\ \text { doi:10.5539/jsd.v6n4p37 } & \text { URL: http://dx.doi.org/10.5539/jsd.v6n4p37 }\end{array}$

\begin{abstract}
Government of Uganda and its development partners are targeting farmer groups as the vehicle for agricultural development because of the potential role they could play in promoting value addition, market and credit access. However there is limited empirical evidence on what drives membership to these groups. Using the Uganda Census of Agriculture 2008/9 data, this study reveals low levels of membership both at individual and household levels, with marked differences in regional participation. The key policy variables found to influence participation in farmer group included education attainment, distance to extension service and quality of road infrastructure. Thus, increasing membership to farmer groups requires government and its development partners to target more resources towards less educated farmers and those who live far from extension workers. The use of the local language in publicity materials is also important in ensuring participation among the illiterate and the less educated. Overall, there is a need for concerted efforts by all institutions supporting groups to ensure that existing groups have improved access to agricultural technologies and noticeable outcomes are achieved so as to attract more farmers.
\end{abstract}

Keywords: farmer group, membership, decision making, Uganda Census of Agriculture

\section{Introduction}

Following the structural adjustment programmes of the mid-1980s, in which several Sub-Saharan Africa governments relinquished support to state controlled co-operatives, farmer groups have emerged in the policy agenda to fill the institution vacuum (FAO, 2010). Uganda is one of the countries with a long history of such farmer groups (see for example, Development Network of Indigenous Voluntary Associations [DENIVA], 2005a; Kyazze, 2010). Farmer groups are groups of farmers that share common interest and come together to share experiences in farming (DENIVA, 2005a). They are usually used as means of reaching smallholder farmers by the government, the private sector and the development partners to improve agriculture productivity and food security. Different terminologies in literature are used to refer to farmer groups including producer organizations, farmer organizations, groups of co-operative action, private co-operatives organisations (Rondot et al., 2001; Uliwa \& Fisher, 2004; Aliguma et al., 2007; Asante et al., 2011). This study (Note 1) refers to them as farmer groups for as long as there was an element of co-operative action on any agricultural activity along the value chain.

Overall, farmer groups are important avenues through which farmers can access market and credit information as well as other important agricultural information like new agricultural technologies. They also form important avenues for mobilizing farmers around a common objective especially in delivery of services and formulation of policies that support agriculture development. In countries such as Tanzania and Ghana, farmer groups are at the centre of the poverty reduction strategy, extension delivery and crop marketing (Uliwa \& Fischer, 2004; Salifu et al., 2010).

In Uganda, the use of farmer groups remains central to the agriculture transformation process. The five year Agriculture Sector Development Strategy and Investment Plan (DSIP) has four pillars: (i) enhancing production and productivity; (ii) improving market access and value addition; (iii) improving the enabling environment for agricultural sector; and (iv) institutional strengthening in the sector (MAAIF, 2010). Under Pillar one and two, the existing farmer groups are envisioned to play a key role in improving produce marketing, increasing access to financing and value addition and ultimately leading to agricultural transformation (MAAIF, 2010). 
As an example, the National Agricultural Advisory Services (NAADS) programme has its implementation strategy based on the farmer group concept. Farmers are supposed to join existing groups or form new groups within the village and then merge to form the village farmer forum. The NAADS programme uses these groups for recruitment of farmers, selection of food security enterprises and distribution of multiplied planting and stocking materials. However, there is limited understanding of the drivers of individual farmer's participation in such groups.

A complete understanding of factors influencing membership to farmer groups could go a long way in informing policy, researchers and development practitioners on how membership can be enhanced and be relied on as channels for agriculture transformation. While there are various organizations and programmes that are supporting the formation of farmer groups in Uganda, the available literature seem to have focused on particular programmes such as NAADS groups and farmer field school (FFS) groups.

Benin et al. (2008), for example, examined the factors that affect household decision to join the NAADS farmer groups. Davis et al. (2010) on the other hand examined the factors that influence the household's decision to participate in FFS groups in East Africa including Uganda. However, besides the NAADS groups and the FFS, other umbrella associations such as the Uganda National Farmers Federation (UNFFE) and the Uganda Cooperative Alliance (UCA) have farmer groups at the grassroots levels that coordinate farmers.

Unlike previous studies that have focused on a specific farmer groups and also using unrepresentative data, this study employs the Uganda Census of Agricultural (UCA) of 2008/9 to provide insights into factors that drive farmer's decision to join any farmer group. The UCA data set is the third and the most recent Uganda agriculture census of its kind, with the first census having been carried out in 1963/04 It had a wide coverage of all the 80 districts in Uganda and given that it is the most recent agriculture census, the recommendations made from this study remains relevant for policy.

The rest of the paper is organized as follows: review of related studies relevant to this study is presented in section 2. The data and methods used in the study are presented in section 3. The results and discussions are provided in section 4, prior to conclusions and policy implications in section 5 .

\section{Review of Related Studies}

Farmer groups are usually formed to facilitate access to better agricultural technologies, to improve access to better earning markets for produce, facilitate produce transport to markets, for financial security and household investments, access to credit where groups members acts as collateral for each other, to invest in agricultural value addition and milk processing plants and in infrastructural development such as rural roads, small power generation projects, schools and health facilities and also in natural resources management and conservation (Loevinsohn et al., 1994; Mutoro, 1997; Aliguma et al., 2007; Gibson et al., 2008; Nyakaana \& Edroma, 2008; UN, 2010; Mwaura et al., 2012; Mbowa et al., 2012).

In other developing countries such as Senegal, farmer groups represent one of the success stories mainly because of the existence of an organized institutional framework with the existence of several federations such as Federation of NGOs in Senegal (FONGS) and National Council for Rural Dialogue and Cooperation (CNCR) (Rondot, 2001). By 2000, FONGS had 24 regionally based associations made up of about 2000 village groups with a membership of 400,000 . About 20 percent of the national population was directly affected by the grass roots activities of FONGS through technical and support activities that they provided. One of key programmes that boost these farmer groups are long term learning by doing programmes which involve a union of Senegalese rural leaders of farmer organization. It involves the leaders meeting three or four times a year to discuss their experiences and receive feedback as a way of improving the performance of their groups. Rural leaders in the community are more likely to have a significant influence in encouraging participation in farmer groups even in the absence of external support ensuring that these groups are long lived and independent (Salifu et al., 2010).

Ghana is also one of those countries where farmer groups are widely used in agriculture development under the Ministry of Food and Agriculture. In 2007, there were over 10,000 farmer groups although they had an average existence of 4.5 years (Salifu et al., 2010). Registration of farmer groups is developed at grassroots level and these are registered at the local, district, and regional levels to a national apex. In addition, there exists the millennium development authority, a public agency that provides training to farmer groups and facilitates investments in business opportunities with farmer based organizations (Asante et al., 2011).

Salifu et al. (2010) found that farmer groups in Ghana appeared greatly homogenous in terms of income and assets and most of them appeared to have emerged from a pre-existing and well defined social cluster or network Participation by farmers in these groups was mainly in anticipation for government and non-governmental 
support rather than an initiative of the community. Their major conclusion was the need to introduce long term learning by doing programmes involving rural leaders as is the case in Senegal. In determining the factors that affect smallholder farmers to join farmer based organizations in Ghana, Asante et al. (2011) found that farm size, farming as a major occupation, access to credit and access to machinery services influenced farmers' decisions to join farmer based organizations in the Eastern Region of Ghana. Farmers were more likely to join farmer groups in order to access such services. To increase membership to farmer groups, they conclude that there was need to increase the availability of credit and the timely provision of machinery services to increase membership to farmer groups.

In Tanzania, an assessment of producer organizations in the country established that there were over 6,000 active farmer organizations with over 250,000 members as of 2003 (Uliwa \& Fisher, 2004). The plausible explanation for this drastic increase may be explained by the favourable policy environment including a Ministry of Marketing and Co-operatives that is intended to guide the activities of farmer groups. Farmer groups are used as avenues for which smallholder farmers can market their produce, access inputs and get extension advice and are characterized by a higher proportion of male members and those producing export crops with high income. Various government and non-governmental organizations support these groups.

Successful interventions have been those that encourage participation by identifying markets and then recruiting groups of farmers to produce those commodities, usually in out-grower schemes like that implemented by Finance and Advice in Development Assistance in Small Enterprise Promotion (FAIDA) in Tanzania under the USAID fund (Uliwa \& Fisher, 2004). A combination of such out-grower schemes and interventions that are aimed at building stronger farmer groups through training of farmers on financial management and leadership would go a long way in encouraging participation and retaining farmers in the groups.

In trying to establish why some farmers do not join farmer groups particularly FFS in Uganda, Davis et al. (2010) found that lack of information, reported by 53.2 percent, was the major cause, followed by lack of time and commitments (reported by 21.3 percent).

DENIVA's (2005a) assessment on the effectiveness of farmer groups as viable institutions for farmer empowerment and poverty reduction in Uganda pointed out that farmer institutional development by the NAADS programme was given a low budget at that time. At the beginning of the NAADS program in 2001, spending was concentrated on management and coordination (e.g. 39 percent in FY2001/2), advisory and information services to farmers (35 percent in FY2001/2) and farmer institutional development (16 percent in FY2001/2). Over the years, spending has tended to focus more on farming technology development and monitoring and evaluation compared to farmer institution development (Benin et al., 2008). These could explain the low participation of farmers in groups in Uganda. In addition, stringent requirements seem to have limited farmers from joining farmer groups. Benin et al. (2008) found that at least 91 percent of the entire farmer groups reported that membership fees was a group eligibility requirement.

Lapple and Van Rensburg (2011) noted that acceptance to participate in farmer's group and adoption of any other agricultural technologies have similarity in that both follow Roger's innovation adoption curve. According to roger's adoption curve, adoption of any new idea is gradual with five categories of adopters. In case of a new idea, the first to adopt are the innovators representing 2.5 percent of the population. They are followed by early adopters, early majority, late majority and laggards each representing $12.5,34,34$, and 16 percent, respectively of the population (Roger, 2003).

Literature reviewed identifies education levels of the household head, participation in nonfarm activities, age, gender, household size, distance to tarmac road, farm size and regulations as some of the potential factors that would influence the decision of households or individual to participate in farmer groups (Davis et al., 2010; Benin et al., 2008; Sabates-Wheeler, 2006; Towo, 2004).

With regards to gender, findings from research work done for groups in Tanzania and farmer field groups in Uganda varied with some showing that women participation is still lower than that of men while others found otherwise (Towo, 2004; Benin et al., 2008). Towo's (2004) work on the relationship between gender and farmer groups in Tanzania found that women participated less in farmer groups than their male counterparts and attributes it to several factors. First, lack of sensitization on gender issues and the heavy domestic workload that women bear makes it difficult for them to attend group formation meetings. Second, groups' focus on export crops in which women involvement is less because they lack control to key production inputs necessary for production like land; and third lack of deliberate efforts to mainstream gender in rural farmer groups through the formulation of pro-gender policies. 
On the other hand, the DENIVA (2005b) on the assessment of the effectiveness of farmer groups as viable institutions for farmer empowerment and poverty reduction found that there were more female members to some of the NAADs groups than their male counterparts. Initially, there was a higher enrolment of males in anticipations of free inputs but later dropped out once their expectations were not realised. The impact evaluation of NAADS in Uganda by Benin et al. (2008) did not find any significant differences in participation in NAADS groups between male and female headed households. Davis et al. (2010) in looking at the impact of FFS on agriculture productivity and poverty in East Africa found a 50 percent probability of women being members in the FFS in Uganda.

With regards to education levels, Davis et al. (2010) found mixed results. While household heads in Kenya with primary and secondary education were more likely to participate in groups (farmer field schools (FFS)) than their counterparts with no education, the reverse was observed for Uganda. Yet, Benin et al. (2008) in looking at the factors that influence the decision for households to join NAADs groups found that farmers with some post-primary education, are more likely to participate in NAADS groups, suggesting that efforts to build capacity of farmers to demand advisory services should be supported by programs that help farmers to improve their education. Indeed, the role of education in influencing farmer group participation in Uganda still has mixed findings given that it could enhance participation or discourage participation in groups.

Mixed findings are also noted with regard to life cycle The life cycle which is captured as aged squared based on the assumption that the network size of an individual increases initially with increase in age, remains relatively constant at ages 35-39 and then declines at an increasing rate after 75 (Morgan, 1988). Younger farmers were more likely to participate in FFS groups than the older farmers in Uganda, Tanzania and Kenya (Davis et al., 2010); whereas Benin et al. (2008) found insignificant results on the decision of a farmer to participate in a NAADS farmer group. Morgan (1988) in a study on age differences in social network participation found that after controlling for resources such as education and health, the network size of an individual increases initially with increase with age, remains relatively constant at ages 35-39 and then declines at an increasing rate after 75. Similarly farmer group participation which entails networking skills given the interactions of an individual with other farmers is likely to follow a similar trend.

The asset value (equipment and land) of the household or farmer is also an important factor that may influence the decision of a farmer to participate in a farmer group. Sabates-Wheeler (2006) in her study on local strategies for survival and growth in Romania and Kyrgyz Republic found that households with less land, labour, arable area owned and equipment were more likely to join groups than their counterparts who owned more land, labour and equipment. Participation in groups was an avenue for these less endowed households and individuals to be able to achieve higher levels of production and manage risk. This is contrary to the findings by Davis et al. (2010) in Uganda. They found that land size was positively correlated to the propensity to participate in FFS. The differences in participation of farmers in the two countries may be attributed to the differences in targeting. In Romania, targeting was towards farmers poor in resources such as land which may not have been the case in Uganda.

Access to infrastructures such as the tarmac road and the market has also been shown to influence membership to farmer groups. Davis et al. (2010) for example found that distance to tarmac roads was negatively related with the propensity to participate in a FFS in Kenya and for all three East African countries combined, suggesting that farmers in remote areas are less likely to take part in the FFS. In Uganda, however, the farther the distance to the tarmac road the more likely an individual will participate in a FFS while in Tanzania distance to tarmac roads had no significant impact on the likelihood of participation. Regarding the distance to the market or urban area, the same study found that distance to nearest market/urban area was positively related to the propensity to participate in FFS in all countries combined and for Kenya and Tanzania. The case for Uganda was contrary-that is, farmers closer to urban areas were less likely to participate in an FFS than those in remote areas. This can probably be explained by the fact that those farmers in town tend to be engaged in other activities other than farming which is usually a secondary activity.

Considering household size as a likely factor that would influence membership to a farmer group, Davis et al. (2010) found that larger household sizes in Kenya were less likely to participate than smaller households. In Uganda and Kenya, the impact was not significant. The dependency ratio (the ratio of the number of dependents divided by the number of working adults) was negatively associated with participation in FFS groups in Uganda; households with a large dependency ratio were less likely to participate. Given that households with a higher dependency ratio are more likely to be poor than those with a lower dependency ratio, the results showed that these groups excluded the poor in Uganda. 
Similarly, Friis-Hansen et al. (2004) in studying smallholder technology development in Soroti: a synergy between NAADS and FFS found that although members of NAADS and FFS had significantly higher technology adoption and use, they were not accessible to the poor farmers and adoption was significantly higher for well off farmers. The study found that the poverty level of non-members of FFS was three times that of members of the group and attributed this to the self-selection process that was common during FFS group formations. The study also pointed out that NAADS groups were formed hurriedly with an external impetus and that mobilization through local government seemed to appeal to the progressive, elite leaders while the poorer sections of the population such as female headed households were excluded.

Literature reviewed above has revealed some of the potential factors that affect farmer participation in specific groups like NAAD groups, FFS groups in Uganda and other kind of groups elsewhere in East Africa. This study fills the gap by looking at farmer groups in general whether self formed groups by farmers or those driven by external funders of groups. It also uses a nationally representative dataset unlike some of earlier studies that used small sample sizes as is the case with Davis et al. (2010).

\section{Data Sources and Empirical Model}

\subsection{Data Sources}

This study employed data from the Uganda Agricultural Census (UCA) of 2008/9 collected by Uganda Bureau of Statistics (UBoS) in collaboration with MAAIF. The census survey was conducted between the months of September 2008 to August 2009 covering 80 districts but focusing on agricultural households. A two stage sampling technique was used to identify households. The first stage involved choosing 3,606 Enumeration Areas (EA) from the four geographical regions namely the Northern, Eastern, Central and Western Uganda. At the second stage 10 households were selected from each selected EAs translating into 31,340 households.

The Census captured information on the agricultural household and holding characteristics including information on the demographic characteristics of household members as well as structural type of data on the agricultural holding; crop area including information on holding parcel and crop plot areas; and (iii) crop production information including quantities production at parcel level by crop. Households were visited twice during the survey period (UBoS, 2008).

\subsection{Empirical Model}

This study postulates that the $i^{\text {th }}$ individual's decision to be a member or a non member of a farmer group $\left(Y_{i}\right)$ is influenced by individual farmer characteristics and household characteristics where a farmer is resident $\left(X_{i}\right)$, and village level characteristics $\left(Z_{i}\right)$ that may promote or impede access to information about group formation. In addition, geographical location represented by regional dummies $\left(R_{i}\right)$ may influence membership to these groups. The error term $\varepsilon_{i}$ is included in the equation to take care of any other factors that might not have been included in the model but may influence farmer's decision to join or not to join a farmer group. The response probability in such a case is expressed as in Equation (1).

$$
P\left(Y_{i}=1 \mid X_{i}\right)=G\left(\alpha+\beta_{i} X_{i}+\gamma_{i} Z_{i}+\delta_{i} R_{i}+\varepsilon_{i}\right)
$$

The function $G$ may take on a linear function in which case it is known as a linear probability model (LPM). LPM may be appropriate for capturing the expected values of farmer group membership but it has some drawbacks such as producing predicted probabilities that are less than zero or greater than one, it implies a constant marginal effect of each explanatory variables that appear in its original form and it contains heteroskedasticity (Wooldridge, 2009). However, this ceases to be a problem in large samples through the use of robust standard errors. To ensure that the explanatory variables take on the values between zero and one, the function $G$ in Equation (1) is either a standard normal cumulative distribution function for a Probit model or a logistic function for a Logit model.

Three models were estimated -LPM, the Logit and the Probit model. Estimation of the probit and logit models was by maximum likelihood which is indispensible for limited independent variables given that it automatically accounts for heteroskedasticity (Wooldridge, 2009).

\section{Description of the model variables}

\section{a) Dependent variable, $\left(Y_{i}\right)$}

The information on membership to farmer group was collected for only those individuals aged 15 years and over. The individual is assigned a value of 1 if he/shewas a member at that time of data collection; otherwise he/she is assigned a value of zero. 


\section{b) Individual and household characteristics, $\left(X_{i}\right)$}

Individual farmer characteristics include: age, age squared, and gender, education attainment, marital status and major economic activities. Farmers may be involved in other economic activities other than agriculture which is their major economic activity, this is reflected in the variable; major economic activity. Age is captured as a continuous variable and we introduce a square of the age variable to account for the effects of the life cycle course on participation in such social networks such as farmer groups as explained in the literature. Education is captured as a categorical variable based on the years of schooling. The distinct categories were no formal education, some primary education, completed primary education, some secondary education and advanced secondary level and above (in which the individual has attended senior five or higher including tertiary education). We also include the household characteristics where an individual is resident. These characteristics include: household composition (household size and share of adults in the household who are above 18 years), and total land holding (in acres).

c) Village level factors, $\left(Z_{i}\right)$

The infrastructure variables included: distance to the produce market (local and district), distance to feeder road, distance to all-year gravel road, and distance to extension service provider, distance to the local input shop, and distance to agriculture nurseries.

d) Sub regional dummies, $\left(R_{i}\right)$

Sub regional dummies were included in the estimation to account for any differences that might arise due to agro-ecological issues, culture, and socio-economic status. An example was the case of whether an individual was a resident of central 2 sub region or not.

Other estimation and data issues that we considered included: missing data, multicollinearity, outliers and sample weights. Missing data is a potential source of bias in survey data analysis, especially if the variable which has missing data is essential in the results outcome (The European Agency for the Evaluation of Medicinal Products, 2001). One of the options is to drop respondents with missing information on the key variables in the analysis and adjust the weighting process, while the other is to impute or substitute a valid response for the missing value (Carson et al., 1995). Kalton (1995) and Engels and Diehr (2003) provide thorough discussions of approaches for inputting missing values in longitudinal data and cross-sectional survey data, including deterministic (e.g. mean, median or modal values) and stochastic (e.g. random regressions) approaches. Of all the approaches, the deterministic approaches are rather common. In this paper, the missing data problem was overcome by replacing the missing data with the median values and not the mean values as is common in most studies.

Outliers were addressed by transforming especially distances using logarithms to make them more normally distributed and in turn improve the regression estimates (see Mukherjee et al., 1998). All estimates both descriptive and econometric estimates were weighted based on the sample weights provided by UBoS.

\section{Empirical Results}

\subsection{Descriptive Results}

This section presents a profiling of membership to farmer groups at both individual and household levels by selected socio-economic characteristics and geographical location. A household is said to be a member of a farmer group when atleast one of its household members belonged to any farmer group during the past 12 months prior to the interview. 


\subsubsection{Incidence of Membership to Farmer Groups}

Table 1. Incidence of membership to farmer groups by gender

\begin{tabular}{|c|c|c|c|c|c|}
\hline \multirow[b]{2}{*}{ Sub-group } & \multicolumn{3}{|c|}{$\begin{array}{c}\text { \%total population } 15 \text { years and } \\
\text { above }\end{array}$} & \multicolumn{2}{|c|}{$\begin{array}{c}\text { Proportion of those in } \\
\text { farmer group who are } 15 \\
\text { years and above. }\end{array}$} \\
\hline & All & Female & Male & Female & Male \\
\hline Uganda & 8.6 & 8.4 & 8.8 & 48.9 & 51.1 \\
\hline \multicolumn{6}{|l|}{ Marital status: } \\
\hline Never married & 2.1 & 2.1 & 2.1 & 41.9 & 58.1 \\
\hline Married & 12.6 & 11.3 & 14.0 & 44.6 & 55.4 \\
\hline Divorced/Separated/Widow & 8.6 & 9.7 & 5.6 & 83.7 & 16.3 \\
\hline No stated & 6.2 & 7.1 & 5.3 & 58.1 & 41.9 \\
\hline \multicolumn{6}{|l|}{ Main economic activity: } \\
\hline Crop agriculture & 11.8 & 11.2 & 12.5 & 50.4 & 49.6 \\
\hline Non-crop agriculture & 13.9 & 13.2 & 14.3 & 33.0 & 67.0 \\
\hline Trader/artisan & 9.6 & 8.7 & 10.0 & 26.8 & 73.1 \\
\hline Paid employment & 7.5 & 8.0 & 7.3 & 32.3 & 67.7 \\
\hline Household work & 5.4 & 5.8 & 4.2 & 81.5 & 18.5 \\
\hline No activity & 2.2 & 1.9 & 2.4 & 41.8 & 58.2 \\
\hline \multicolumn{6}{|l|}{ Region: } \\
\hline Central: & 5.8 & 5.6 & 6.0 & 48.9 & 51.1 \\
\hline Kampala & 6.0 & 8.0 & 4.1 & 63.3 & 36.7 \\
\hline Central 1 & 6.7 & 6.4 & 7.0 & 49.0 & 51.0 \\
\hline Central 2 & 4.9 & 4.6 & 5.2 & 47.4 & 52.6 \\
\hline Eastern: & 7.8 & 7.7 & 7.9 & 48.9 & 51.1 \\
\hline East Central & 5.6 & 5.6 & 5.7 & 48.7 & 51.3 \\
\hline Eastern & 9.1 & 9.0 & 9.2 & 47.8 & 52.2 \\
\hline Northern: & 11.8 & 11.0 & 12.5 & 47.1 & 52.8 \\
\hline Mid-North & 13.5 & 13.1 & 13.9 & 47.8 & 52.2 \\
\hline North East & 14.7 & 13.3 & 16.2 & 48.2 & 51.8 \\
\hline West Nile & 8.0 & 7.1 & 9.0 & 44.8 & 55.1 \\
\hline Western: & 8.6 & 8.8 & 8.4 & 50.5 & 49.5 \\
\hline Mid-West & 7.3 & 7.0 & 7.6 & 47.1 & 52.9 \\
\hline South-Western & 9.6 & 10.1 & 9.0 & 52.1 & 47.5 \\
\hline Number of Observations & 94,731 & 4219 & 4247 & 4219 & 4247 \\
\hline
\end{tabular}

Note: Analysis done at individual level.

Source: Authors calculation based on UCA 2008/9.

The incidence of individual membership to a farmer group is presented in Table 1 while the incidence of household membership to groups is reported in Appendix 2. Nationally, only 9 percent of the agricultural households above 15 years of age reported being a member of a farmer group during the past 12 months prior to the interview. At household level, only 16 percent of households were members to a farmer group. No large differences in female and male membership to farmer groups were observed at individual level. Regionally, Northern region leads other regions at 11.8 percent and Central region lags at 5.8 percent. Yet, these regional averages conceal sub-regional variations as illustrated in the Table 1. Table 1 further shows that married individuals were more likely to be members of a farmer group as compared to unmarried individuals. Notable in Table 1 however is that women who were divorced, separated or widows were more likely to belong to farmer groups (84\%) than their male counterparts (16\%).

Individuals whose main economic activity was agriculture (crop and non-crop) were more likely to be in farmer groups relative to their counterparts in other economic activities. The relatively higher incidence of individuals whose main economic activity is non-crop agriculture compared to their counterparts in crop agriculture could be explained as follows: Either farmers find it more fulfilling to join farmer groups whose intention is directed towards non-crop activities or available government programmes or NGOs have their priorities directed towards non-crop activity. A study by Okoboi et al. (2011) on the economic and institutional efficiency of the NAADS programme revealed that longer term enterprises like dairy cattle, piggery and poultry were given priority and 
dictated upon to the NAADS farmers. Broadly speaking, the low incidence of membership is a concern on the effectiveness of the recruitment efforts of Government programmes such as NAADS and Northern Uganda Social Action Fund (NUSAF), which directly target farmers organised in groups.

Following the literature reviewed, the low membership to farmer groups may be explained by the lack of information, the low budgetary allocations to farmer institution development by the NAADS programme and the stringent membership requirements (DENIVA, 2005b; Benin et al., 2008; Davis et al., 2010). Farmer groups in Uganda also appear to be at an early stage with only innovators and early adopters having enrolled (Lapple \& Van Rensburg, 2011). The challenge to policymakers therefore is to ensure that the institution of farmer group effectively attracts the early majority, late majority and the laggards.

The findings in Table 1 reveal that Northern region had high membership to farmer groups in Uganda yet this region was highly affected by the 20 year old insurgency. This could be attributed to the surge of government programmes and international development agency support that emerged in the pre- and post-conflict era in the region. The Government of Uganda embarked on several programmes in an attempt to try to rebuild and empower communities. These programmes some of which are still being implemented include: the NUSAF; Peace Recovery and Development Plan (PRDP), Acholi Programme; Restocking Programme; and Karamoja Development Programmes. Other humanitarian organizations such as UNICEF and World Food Organization are also providing services to these people. The overall strategy for most of these programmes particularly in providing livelihood support and protection was to target the vulnerable people organized in groups. The NUSAF, for example directs support to organized groups that are implementing income generating activities such as apiary, zero-grazing, poultry, vegetable growing and marketing and grain milling.

At household level, the patterns across regions and economic activity mirror those observed at individual level, albeit with slightly higher levels of membership overall (16\%) (Figure1; for details, see Appendix 2).

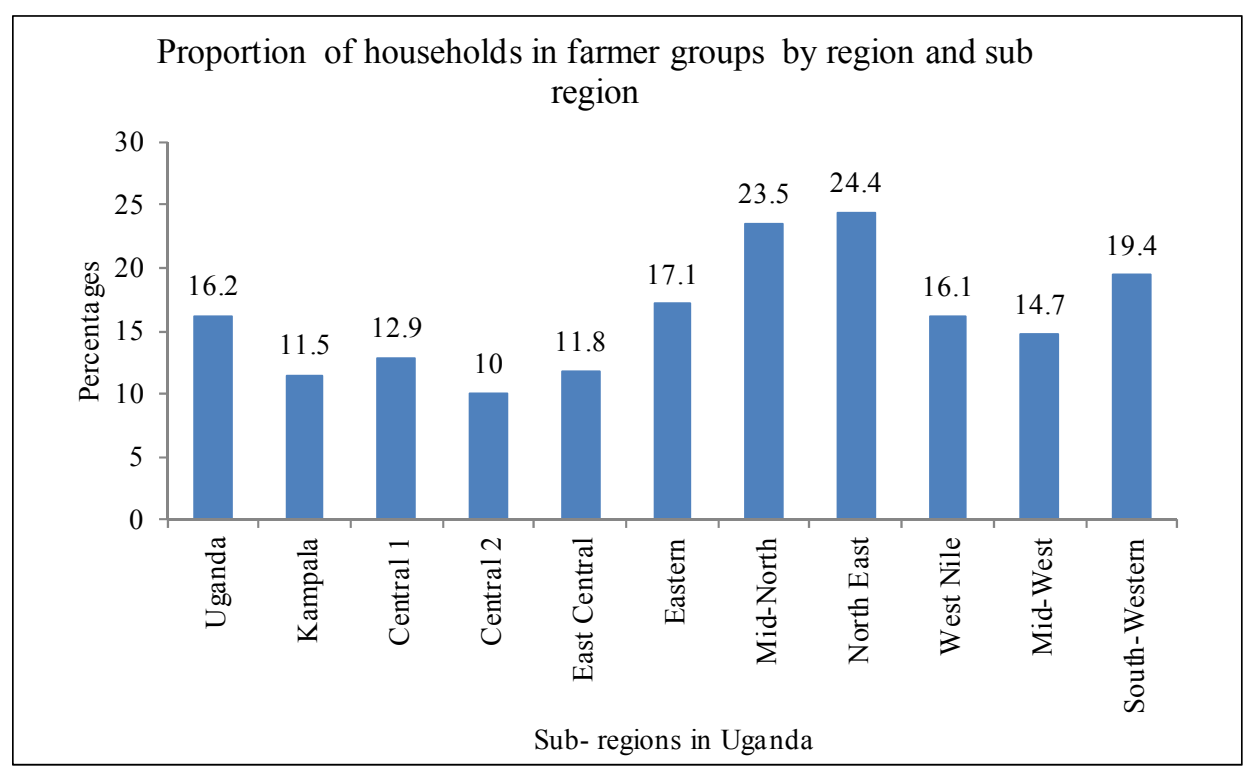

Figure 1. Showing household membership to farmer groups in Uganda by sub region

\subsubsection{Comparisons of Selected Characteristics between Member and Non-Membership to Farmer Group}

Farmers who were members of farmer groups were more likely to be older, males, literate and with better asset portfolio and better access to credit (Table 2). It is further noted that these individuals were more likely to be residents in households with larger land size and higher composition of adults. The latter implies that the households were associated with higher labour force supply. The results in Table 2 further reveal significant differences the characteristics of the household heads with and without household members enrolled in farmer groups. 
Table 2. Differences in selected characteristics by farmer group membership

\begin{tabular}{lccc}
\hline & \multicolumn{2}{c}{ Membership status } & \multirow{2}{*}{ t-statistic } \\
\cline { 2 - 3 } & Non-member & Member & \\
\cline { 1 - 2 } Individual characteristics: & 36.0 & 40.5 & 16.7 \\
Age, in years & 48.6 & 49.9 & 2.1 \\
\% males & 5.5 & 5.5 & 0.2 \\
Years of schooling & 67.2 & 70.9 & 3.0 \\
Literacy rate, \% & 58.8 & 83.2 & 26.7 \\
Manages a plot, \% & 36.4 & 69.2 & 26.6 \\
Owns livestock, \% & 3.6 & 19.4 & 15.3 \\
Access to credit, \% & & & \\
Household characteristics: & 6.3 & 6.6 & 2.8 \\
Household size & 0.9 & 1.2 & 3.6 \\
Land under cultivation & & & \\
Demographic composition: & 12.1 & 12.5 & 0.9 \\
$\quad$ - Children <=5 yrs & 29.9 & 34.2 & 7.0 \\
$\quad$ - Children 6-17 yrs & 49.7 & 47.7 & -2.6 \\
$\quad$ - Adults 18-59 yrs & 82.9 & 84.0 & 1.2 \\
Male headed, \% & & & \\
Characteristics of household head: & 44.8 & 45.3 & \\
Age, in years & 5.1 & 5.8 & \\
Years of schooling & 66.2 & 75.8 & \\
Literacy rates, \% & &
\end{tabular}

Source: Authors' calculation based on UCA 2008/9.

There is no doubt that access to information is important to agricultural households if they are to improve on their farming practices, access markets for both inputs and outputs and adopt new technologies that will ensure productivity increments. Regardless of membership status, it is evident from Table 3 that the major source of information on weather and credit facilities was through radio, followed by farmer to farmer (at about 12 percent for non-members relative to 10 percent for members). On the other hand, farmer to farmer was an important source for information on crop varieties and agriculture practices, with a higher incidence among those households without members in farmer groups. More notably, households with at least a member in a farmer group were more likely to cite NAADS and extension worker as a source of information on crop variety and agricultural practices compared to their counterparts without such membership.

Farmer to farmer interactions was a major information source on pest and diseases and marketing for all households followed by radio. Like in the previous cases, NAADS and the use of extension workers were reported more by those in groups compared to their counterpart households that are not in groups. Particularly, 21 percent of households with a member in a group reported NAADS as a major information source on pest and diseases compared to only 5 percent reported by those not in groups. Similarly, 11 percent of those in groups reported NAADS as a major information source on marketing information compared to only 2 percent reported by their counterparts not in groups.

Overall, households with no members in farmer groups were more likely to cite farmer to farmer as a main source of agricultural information -implying that informal networks are still strong within farming households and attempts to improve on them could go a long way in promoting growth within the agriculture sector. On the other hand, households with members in farmer groups were more likely to report formal source of agricultural information including NAADS and the use of extension workers. 
Table 3. Main source of information related to agriculture by membership status (Percentages)

\begin{tabular}{|c|c|c|c|c|c|c|c|c|c|c|c|c|}
\hline \multirow{2}{*}{ Source } & \multicolumn{3}{|c|}{ Weather } & \multicolumn{3}{|c|}{ Crop varieties } & \multicolumn{3}{|c|}{ New agric. Practices } & \multicolumn{3}{|c|}{ Farm machinery } \\
\hline & $\begin{array}{l}\text { Non-me } \\
\text { mber }\end{array}$ & $\begin{array}{c}\text { Mem } \\
\text { ber }\end{array}$ & All & $\begin{array}{l}\text { Non-me } \\
\text { mber }\end{array}$ & $\begin{array}{c}\text { Mem } \\
\text { ber }\end{array}$ & All & $\begin{array}{c}\text { Non-me } \\
\text { mber }\end{array}$ & $\begin{array}{c}\text { Mem } \\
\text { ber }\end{array}$ & All & $\begin{array}{l}\text { Non-me } \\
\text { mber }\end{array}$ & $\begin{array}{c}\text { Mem } \\
\text { ber }\end{array}$ & All \\
\hline Radio & 84.8 & 86.6 & 85.1 & 41.2 & 27.9 & 39.0 & 38.7 & 22.2 & 35.8 & 46.2 & 31.8 & 43.7 \\
\hline Modern ICT & 1.0 & 0.9 & 0.9 & 1.0 & 1.4 & 1.0 & 1.0 & 1.3 & 1.1 & 1.2 & 0.7 & 1.1 \\
\hline $\begin{array}{l}\text { Farmer to } \\
\text { farmer }\end{array}$ & 12.3 & 10.0 & 11.9 & 45.4 & 30.9 & 43.0 & 42.3 & 26.1 & 39.5 & 33.5 & 26.2 & 32.3 \\
\hline NAADs & 0.2 & 1.1 & 0.4 & 5.9 & 25.5 & 9.3 & 9.3 & 32.8 & 13.4 & 4.5 & 19.4 & 7.1 \\
\hline $\begin{array}{l}\text { Extension } \\
\text { worker }\end{array}$ & 0.3 & 0.6 & 0.3 & 3.1 & 10.8 & 4.4 & 4.3 & 13.4 & 5.9 & 2.8 & 9.3 & 3.9 \\
\hline Others & 0.6 & 0.2 & 0.5 & 1.8 & 2.4 & 1.9 & 3.0 & 2.8 & 2.9 & 6.5 & 8.0 & 6.7 \\
\hline Not stated & 0.9 & 0.5 & 0.8 & 1.5 & 1.1 & 1.4 & 1.5 & 1.3 & 1.4 & 5.3 & 4.6 & 5.2 \\
\hline $\begin{array}{l}\text { Est. HHHs } \\
' 000\end{array}$ & $2,723.3$ & 526.0 & $\begin{array}{c}3,24 \\
9.3\end{array}$ & $2,598.3$ & 528.6 & $\begin{array}{c}3,12 \\
6.9\end{array}$ & $2,312.9$ & 488.4 & $\begin{array}{c}2,80 \\
1.2\end{array}$ & $1,660.7$ & 341.8 & $\begin{array}{c}2,00 \\
2.5\end{array}$ \\
\hline
\end{tabular}

Table 3. Main source of information related to agriculture by membership status (Percentages) (continued)

\begin{tabular}{lccccccccc}
\hline \multirow{2}{*}{ Source } & \multicolumn{3}{c}{ Credit facilities } & \multicolumn{3}{c}{ Plant diseases/pests } & \multicolumn{4}{c}{ Marketing } \\
\cline { 2 - 10 } & Non-member & Member & All & Non-member & Member & All & Non-member & Member & All \\
\hline Radio & 51.8 & 42.6 & 50.2 & 39.7 & 27.6 & 37.7 & 38.7 & 35.0 & 38.1 \\
Modern ICT & 0.7 & 0.5 & 0.7 & 0.5 & 0.3 & 0.5 & 1.4 & 1.2 & 1.4 \\
Farmer to farmer & 36.5 & 29.5 & 35.3 & 47.9 & 33.0 & 45.4 & 52.3 & 42.7 & 50.8 \\
NAADs & 3.4 & 11.8 & 4.9 & 5.1 & 20.5 & 7.7 & 2.0 & 11.0 & 3.5 \\
Extension worker & 1.6 & 8.2 & 2.7 & 3.5 & 15.0 & 5.4 & 1.4 & 5.9 & 2.1 \\
Others & 1.8 & 2.5 & 1.9 & 2.2 & 2.4 & 2.2 & 1.6 & 1.5 & 1.6 \\
Not stated & 4.3 & 4.9 & 4.4 & 1.1 & 1.2 & 1.1 & 2.5 & 2.7 & 2.6 \\
Est. HHHs '000 & $1,896.6$ & 397.2 & $2,293.8$ & $2,535.9$ & 502.3 & $3,038.2$ & $2,423.7$ & 459.4 & $2,883.1$ \\
\hline
\end{tabular}

Source: Authors calculation based on UCA 2008/9.

Table 4. Household: Membership by use of agricultural inputs during the past 12 months, $\%$

\begin{tabular}{lccc}
\hline & \multicolumn{2}{c}{ Membership to groups } & \multirow{2}{*}{ All } \\
\cline { 2 - 3 } & Non-member & Member & \\
\hline Local seeds & 93.5 & 94.2 & 93.3 \\
Improved/Hybrid seeds & 30.2 & 45.8 & 31.7 \\
Organic fertilizer & 24.1 & 35.7 & 25.3 \\
Inorganic fertilizer & 7.7 & 13.0 & 8.2 \\
Pesticides: Herbicides & 9.1 & 15.4 & 9.3 \\
$\quad$ Fungicides & 5.4 & 10.9 & 6.0 \\
$\quad$ Pesticides & 17.0 & 28.7 & 18.3 \\
$\quad$ Other pesticides & 6.7 & 11.2 & 7.3 \\
Commercially prepared Animal feeds & 3.4 & 6.0 & 3.7 \\
Veterinary drugs & 28.3 & 47.1 & 30.0 \\
Insemination & 1.9 & 2.8 & 1.9 \\
Number of observations & 25909 & 5212 & 31121 \\
\hline
\end{tabular}

Source: Authors calculation based on UCA 2008/9.

The results in Table 4 show the incidence of agricultural input use by membership status. The use of agricultural inputs is important if productivity is to be enhanced. Farmer groups are known to be avenues that facilitate and link farmers to new technologies and production practices. It is evident that households with a member in a 
group were more likely to use modern agricultural technologies compared to their counterparts with no household member in group. With regard to use of local seeds, no noteworthy differences were observed across membership in farmer groups. However, it is important to point out that the most applied modern technologies were improved seeds followed by veterinary drugs and pesticides.

\subsection{Econometrics Model}

Results of the LPM, Probit and Logit models are presented in Appendix 3. The coefficients of the models differ in magnitude but are similar in direction-implying they speak the same language but at different levels. In this paper, we focus the discussion on the probit estimates-transformed into marginal effects and presented in Table 5. It is evident that individual characteristics including age, gender, marital status and education do influence a farmer's decision to enrol in a farmer group. Specifically, older farmers are more likely to join farmer groups compared to the younger farmers by a 0.9 percent probability. There are regional variations that ranged from 1.1 percent for Northern Uganda to 0.8 percent for Eastern region. Upon controlling for other factors, the results reveal that male farmers are less likely to be members relative to their female counterparts. This finding contrasts the descriptive statistics that seem to portray that males are more likely to join famers relative to female farmers.

Education is a very important factor influencing the farmer's decision to be a member of a farmer group. Similar results are reported by Benin et al. (2008).The results suggest that the higher the education level, the higher the probability of being a member for all the regions. For Western region, for example, the likelihood of an individual who has completed secondary education and above is more than three-times that of an individual who has only attained some primary education. This finding could imply that much as the majority of the farmers have less than 5 years of formal schooling, those with higher education levels are more likely to take advantages of the benefits that come with joining farmer groups. Given the low levels of education of the agricultural households, there should be deliberate efforts to build capacities of individuals in these households that will enable them to join farmer groups.

Table 5. Probit model estimates for determinants of Farmer group membership in Uganda (Marginal effects)

\begin{tabular}{|c|c|c|c|c|c|}
\hline & \multicolumn{5}{|c|}{ Regions } \\
\hline & National & Central & Eastern & Northern & Western \\
\hline \multicolumn{6}{|l|}{ Individual characteristics } \\
\hline Age & $\begin{array}{c}0.009 * * * \\
{[0.00]}\end{array}$ & $\begin{array}{c}0.009 * * * \\
{[0.00]}\end{array}$ & $\begin{array}{c}0.008^{* * *} \\
{[0.00]}\end{array}$ & $\begin{array}{c}0.011 * * * \\
{[0.00]}\end{array}$ & $\begin{array}{c}0.008 * * * \\
{[0.00]}\end{array}$ \\
\hline Age squared & $\begin{array}{c}-0.083^{* * *} \\
{[0.01]}\end{array}$ & $\begin{array}{c}-0.083 * * * \\
{[0.01]}\end{array}$ & $\begin{array}{c}-0.080^{* * *} \\
{[0.01]}\end{array}$ & $\begin{array}{c}-0.110^{* * *} \\
{[0.01]}\end{array}$ & $\begin{array}{c}-0.075 * * * \\
{[0.01]}\end{array}$ \\
\hline Farmer is male & $\begin{array}{c}-0.008 * * * \\
{[0.00]}\end{array}$ & $\begin{array}{c}-0.004 \\
{[0.00]}\end{array}$ & $\begin{array}{c}-0.011 * * * \\
{[0.00]}\end{array}$ & $\begin{array}{c}-0.008 \\
{[0.01]}\end{array}$ & $\begin{array}{c}-0.004 \\
{[0.00]}\end{array}$ \\
\hline \multicolumn{6}{|c|}{ Marital status of the farmer (cf:Never married) } \\
\hline Married & $\begin{array}{c}0.045^{* * *} \\
{[0.01]}\end{array}$ & $\begin{array}{c}0.019 * * \\
{[0.01]}\end{array}$ & $\begin{array}{c}0.042 * * * \\
{[0.01]}\end{array}$ & $\begin{array}{c}0.047 * * * \\
{[0.01]}\end{array}$ & $\begin{array}{c}0.061 * * * \\
{[0.01]}\end{array}$ \\
\hline Widowed and not remarried & $\begin{array}{c}0.050 * * * \\
{[0.01]}\end{array}$ & $\begin{array}{c}0.016 \\
{[0.01]}\end{array}$ & $\begin{array}{c}0.042 * * \\
{[0.02]}\end{array}$ & $\begin{array}{l}0.039 \\
{[0.03]}\end{array}$ & $\begin{array}{c}0.088^{* * *} \\
{[0.02]}\end{array}$ \\
\hline Divorced and not remarried & $\begin{array}{c}0.023^{*} \\
{[0.01]}\end{array}$ & $\begin{array}{l}-0.001 \\
{[0.01]}\end{array}$ & $\begin{array}{l}0.009 \\
{[0.02]}\end{array}$ & $\begin{array}{l}0.032 \\
{[0.03]}\end{array}$ & $\begin{array}{c}0.028 \\
{[0.02]}\end{array}$ \\
\hline Married but separated & $\begin{array}{l}-0.011 \\
{[0.01]}\end{array}$ & $\begin{array}{c}-0.022^{*} \\
{[0.01]}\end{array}$ & $\begin{array}{l}0.001 \\
{[0.02]}\end{array}$ & $\begin{array}{l}-0.032 \\
{[0.03]}\end{array}$ & $\begin{array}{l}0.001 \\
{[0.02]}\end{array}$ \\
\hline \multicolumn{6}{|c|}{ Education level of the farmer (cf:No education) } \\
\hline Some primary & $\begin{array}{c}0.035^{* * *} \\
{[0.01]}\end{array}$ & $\begin{array}{c}0.023 * * \\
{[0.01]}\end{array}$ & $\begin{array}{c}0.018 * * \\
{[0.01]}\end{array}$ & $\begin{array}{c}0.035 * * * \\
{[0.01]}\end{array}$ & $\begin{array}{c}0.028 * * * \\
{[0.01]}\end{array}$ \\
\hline Completed primary & $\begin{array}{c}0.064 * * * \\
{[0.01]}\end{array}$ & $\begin{array}{c}0.055^{* * *} \\
{[0.01]}\end{array}$ & $\begin{array}{c}0.065 * * * \\
{[0.01]}\end{array}$ & $\begin{array}{c}0.070 * * * \\
{[0.02]}\end{array}$ & $\begin{array}{c}0.037 * * * \\
{[0.01]}\end{array}$ \\
\hline Some secondary & $\begin{array}{c}0.097 * * * \\
{[0.01]}\end{array}$ & $\begin{array}{c}0.064 * * * \\
{[0.01]}\end{array}$ & $\begin{array}{c}0.076^{* * *} \\
{[0.01]}\end{array}$ & $\begin{array}{c}0.127 * * * \\
{[0.02]}\end{array}$ & $\begin{array}{c}0.071 * * * \\
{[0.01]}\end{array}$ \\
\hline $\begin{array}{l}\text { Advanced secondary level and } \\
\text { higher }\end{array}$ & $\begin{array}{c}0.137 * * * \\
{[0.02]}\end{array}$ & $\begin{array}{c}0.086 * * * \\
{[0.03]}\end{array}$ & $\begin{array}{c}0.144 * * * \\
{[0.03]}\end{array}$ & $\begin{array}{c}0.148 * * * \\
{[0.04]}\end{array}$ & $\begin{array}{c}0.103 * * * \\
{[0.03]}\end{array}$ \\
\hline \multicolumn{6}{|c|}{ Major economic activity of the farmer (cf:crop agriculture) } \\
\hline Non crop agriculture & $\begin{array}{c}0.012 \\
{[0.01]}\end{array}$ & $\begin{array}{c}0.007 \\
{[0.01]}\end{array}$ & $\begin{array}{l}-0.011 \\
{[0.02]}\end{array}$ & $\begin{array}{c}0.082 * * * \\
{[0.03]}\end{array}$ & $\begin{array}{l}-0.022 \\
{[0.02]}\end{array}$ \\
\hline
\end{tabular}




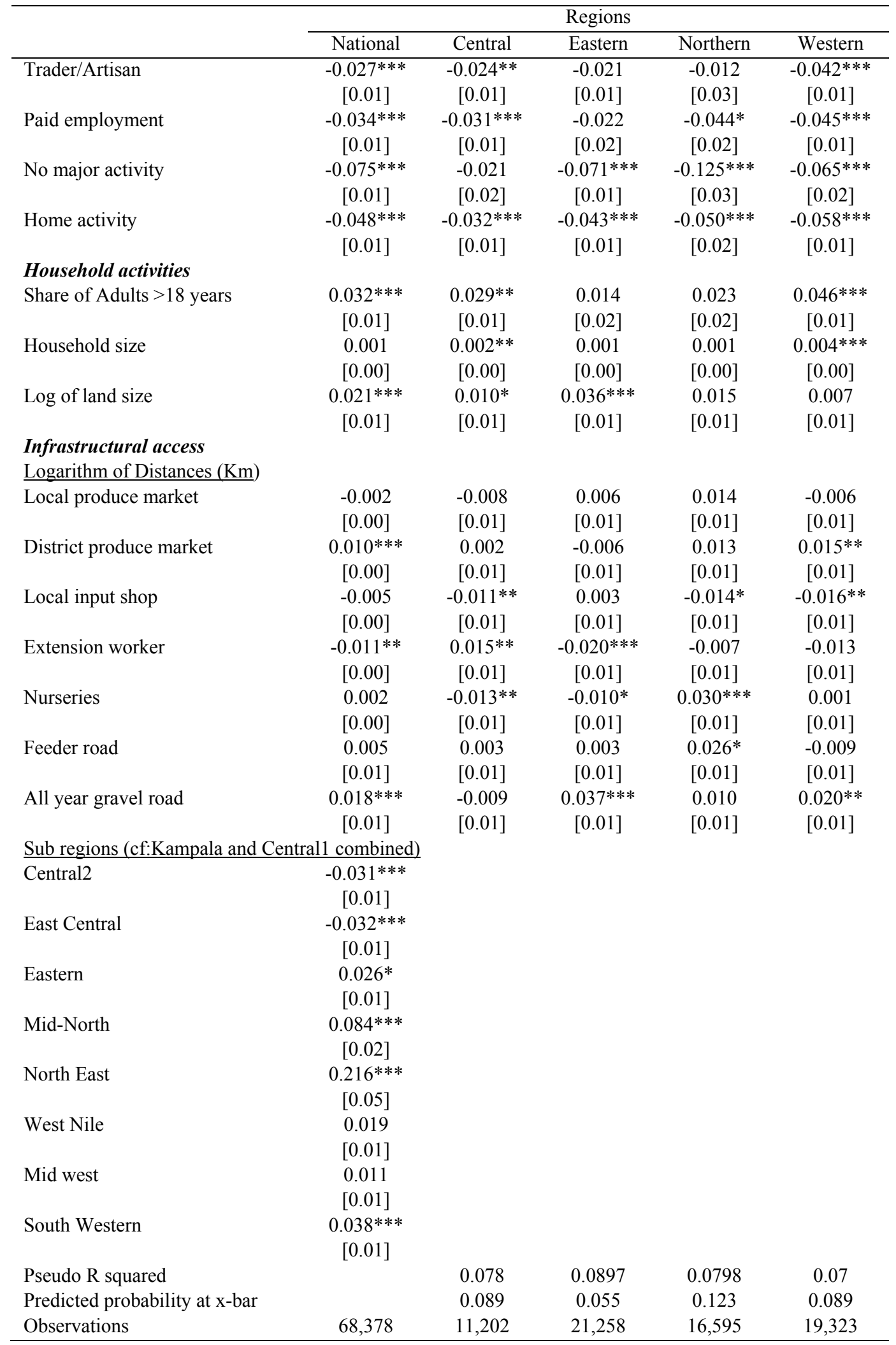

Notes: $* * *, * *$ and $*$ indicates statistical significance at 1,5 and $10 \%$ level $(\mathrm{p}=0.01,0.05$ and 0.1$)$. Regression is at individual level.

Source: Authors calculation based on UCA 2008/09 
Generally, farmers in economic activities other than crop agriculture and non-crop agriculture (such as traders or those in paid employment)as would be expected are less likely to be members of a farmer group. In Northern Uganda, farmers whose main economic activity is non-crop agriculture have 8 percent more likelihood of being in groups than their counterparts who are in crop agriculture. This may be attributed to the fact that the major economic recovery programmes in Northern Uganda such as NUSAF prioritize non agricultural enterprises more than crop agricultural enterprises through provision of improved breeds and the control of livestock diseases (GoU, 2010). The lifecycle and household composition matters for one to join the farmer groups. Agricultural activities are associated with intensive labour demands. Results from Table 5 show that Individual farmers resident in households with a higher share of adult members above 18 years of age are more likely to join the farmer groups. However, there are variations across regions as shown in Table 5. The finding is not significant for individuals in Eastern and Northern regions - which are the same regions that were part of the NUSAF project at the time of the Census.

The total land owned by the household is also an important factor influencing membership to a farmer group at national level and in Central and Eastern Uganda. However, it is an insignificant factor in influencing membership in Northern and Western Uganda.

Access to infrastructure mainly in terms of distance to extension worker also affects the decision to join the groups at national level but varies amongst regions. At national level, those far away from an extension worker are one percent less likely to join a farmer group compared to those close to the extension worker. In Eastern Uganda, those far away from an extension worker are about two percent less likely to join farmer groups. In Central Uganda, positive and statistically significant relationship between distance to the extension worker and membership to farmer group is observed. It is not clear why this may be the case, but may be related to better road infrastructure in the region.

The distances to all year gravel road and the district produce markets show that the farther away a farmer is from these infrastructures, the more likely they will join groups. Davis et al. (2010) also finds contrasting results in terms of distances to urban areas and membership in FFS in Uganda.

Finally, there also exist sub regional differences in the likelihood of farmers being members of the group within the different regions when compared to Central 1 and Kampala sub regions. The presence of government programmes such as the PRDP and NUSAF and the sprouting up of Non Governmental organizations following post conflict period may explain the variation and significance of farmer group membership in the northern sub-regions compared to Central 1 and Kampala. In addition, the low membership to farmer groups in the combined two sub regions of Central 1 and Kampala may be associated with the fact that access to agricultural services like input shops is within easy reach of farmers such that they become reluctant to join the groups. It could also be attributed to the fact that these are regions where the capital city is located with substantial proportion of the population having formal employment and not agriculture as their primary source of income. They may therefore have a lower desire and time to join farmer groups.

\section{Conclusions and Policy Recommendations}

Using data from the Uganda Census of Agriculture of 2008/09, this study has provided insights into the factors that influence the individual farmer's decision to join farmer groups. Despite the benefits that come with belonging to farmer groups, 9 percent of the adult farming population in 16 percent of the agricultural households were members of farmer groups. The observed rather high level of membership to groups in Uganda's lagging Northern region is partly attributed to the government interventions through NUSAF and NAADS programs. The level of membership to groups remains low for government to use this institution (farmer group) as a vehicle for transforming agriculture in Uganda. More importantly, this finding questions the effectiveness of the approaches used by both Government and NGOs to lure farmers to join and be retained in groups. The challenge is to ensure that this institution effectively attracts the early majority, late majority and the laggards.

Results of the study suggest that individual characteristics including age and sex of the farmer as well as regional location of the households matter to group membership. The likelihood to join a farming group increases with education attainment as well as being residence in a household with more cultivable land and better access to services including extension. Education levels in Uganda remain low with the majority of the population having an education below primary level (UBoS, 2010), it is therefore important that appropriate recruitment efforts are used during the process of group formation.

For example, although NAADS implementation guideline clearly stipulates a stepwise strategy that allows farmers to be mobilised and educated on the importance of farmers groups, it has been observed that group 
formation has often been done in a hurry denying would be participants' time to understand and enrol (Friis-Hansen et al., 2004). This observation calls for a well organized and planned recruitment that considers the level of education among farmers to ensure more participation. In the short run, government might have to organize 'non-school' education for farmers (for example, through incorporating it in on-going Government programs like NAADS and NUSAF) because school-based education will take a long time to deliver to farmers.

Additionally, publicity and farmer education on group formation should be given more adequate time and resources with targeting directed towards illiterate farmers and those far away from extension workers. Findings of the study reveal that "radio" and "farmer to farmer" communication are the most important methods for getting information to farmers on a variety of topics regardless of whether they are in farmer groups or not. Farmers also usually meet in community gatherings like community meetings, churches and usually visit places like hospitals and sub county headquarters. Publicity on the importance of group formation should be at such gatherings and posters having information on group information should be displayed in such places. Other avenues such as radios should also be used for educating farmers on the importance of group formation. Lastly, the teachers given their respected roles in the community and their access to people through children can be supported to publicize the importance of farmer group membership in efforts to transform agriculture. All the materials used in publicity materials should be translated into the local languages as it is important in ensuring that also the illiterate farmers understand the concept of group formation.

The low participation in farmer groups in Uganda also calls for concerted efforts by all institutions (NAADS, UNFFE, World food programme and Uganda Co-operative Alliance, among others) supporting groups to ensure that groups' approach succeeds in improving access to agricultural technologies and ensuring that noticeable outcomes are achieved for them to attract more farmers. Supporting out grower schemes like that of Ghana could be one such avenue.

Overall this study has been able to establish and explain the factors that affect participation in farmer groups in Uganda. However due to data limitations, it was unable to explain the weaknesses of the current groups in relation to group formation and membership retention and this could be an area of further research.

\section{References}

Adong, A., Mwaura, F., \& Okoboi, G. (2012). What factors affect membership to farmer groups in Uganda. Retrieved from http://ageconsearch.umn.edu/bitstream/126774/2/AdongWCover.pdf

Aliguma, L., Magala, D., \& Lwasa, S. (2007). Uganda: Connecting small-scale producers to markets: The case of the Nyabyumba United Farmers Group in Kabale district, Regoverning Markets Innovative Practice series. London: IIED.

Asante, B. O., Sefa, V. A., \& Sarpong, D. B. (2011). Determinants of small scale farmers' decision to join farmer based organizations in Ghana. Africa Journal of Agricultural Research, 6(10), 2273-2279.

Bennin, S., Nkonya, E., Oketcho, G., Randriamamonji, J., Kato, E., Lubade, G., ... Byekwaso, F. (2008). Impact Evaluation of the National Agricultural Advisory Services (NAADS) in Uganda. Final draft.

Carlson, B. L., Cox, B. G., \& Bandeh, L. S. (1995). SAS macros useful in imputing missing survey data. Mathematica Policy Research Inc., Princeton, New Jersey. Retrieved from http://mathematica.mpr.org/publications/PDFs/misssurdata.pdf

Davis, K., Nkonya, E., Kato, D. A., Mekonnen, M., Odendo, R. M., \& Nkuba, J. (2010). Impact of Farmer Field Schools on Agricultural Productivity and Poverty in Uganda. IFPRI Discussion Paper 00992 June 2010.

Development Network of Indigenous Voluntary Associations (DENIVA). (2005a). Uganda: Trade Liberalisation and its impact on Poverty. Country Background Paper.

Development Network of Indigenous Voluntary Associations (DENIVA). (2005b). Effectiveness of farmer groups as viable institutions for farmer empowerment and poverty reduction in the implementation of the plan for the modernization of Agriculture (PMA). Retrieved from http://www.deniva.or.ug/files/programme-agriculturetrade_research_farmergroups.pdf

Engels, J. M., \& Diehr, P. (2003). Imputation of missing longitudinal data: a comparison of methods. Journal of Clinical Epidemiology, 56, 968-976. http://dx.doi.org/10.1016/S0895-4356(03)00170-7

Friis-Hansen, E., Aben, C., \& Kidoid, M. (2004). Small holder agricultural technology development in Soroti district: Synergy between NAADS and Farmer Field Schools, Uganda. Journal of Agricultural Sciences, 2004, 250-256. Uganda Agricultural Research Organization. 
Food and Agriculture Organisation (FAO). (2010). Producer Organisations: Reducing opportunities for Development. Policy brief.

Gibson, R. W., Byamukama, E., Mpembe, I., Kayongo, J., Mwanga, R. O. (2008). Working with farmer groups in Uganda to develop new sweet potato cultivars: decentralisation and building on traditional approaches. Euphytica, 159, 217-228. http://dx.doi.org/10.1007/s10681-007-9477-4

Government of Uganda (GoU). (2007). Peace Recovery and Development Plan for Northern Uganda (PRDP) 2007-2010.

Gujarati, D. (2003). Basic econometrics. Boston, USA: McGraw Hill.

Kalton G., \& Kasprzyk, D. (1995). The treatment of missing survey data. Journal of Official Statistics, 11, 181-204.

Kyazze, L. M. (2010). Cooperatives: The Sleeping economic and social giants in Uganda. Coopafrica Working Paper No. 15.

Läpple, D., \& Van Rensburg, T. (2011). Adoption of organic farming: Are there differences between early and late adoption? Ecological Economics, 70(7), 1406-1414. http://dx.doi.org/10.1016/j.ecolecon.2011.03.002

Loevinsohn, M. E., Mugaruraand, J., \& Nkusi, J. (1994). Cooperation and innovation by farmers groups: scale in the development of Rwandan Valley farming systems. Agricultural Systems, 46(2), 141-155. http://dx.doi.org/10.1016/0308-521X(94)90094-V

Mbowa, S., Shinyekwaand, I., \& Mayanja, M. (2012). Dairy sector reform and transformation in Uganda since the 1990s. EPRC Research Report No.4 Uganda.

Ministry of Agriculture, Animal Industry and Fisheries (MAAIF). (2010). Agriculture for Food and Income Security: Agriculture Sector Development Strategy and Investment Plan 2010/11-2014/15. Kampala, Uganda: MAAIF.

Morgan, D. L. (1988). Age Differences in Social Network Participation. Journal of Gerontology: Social Sciences, 43(4), S129-137.

Mukherjee, C., White, H., \& Wuyts, M. (1998). Econometrics and Data Analysis for Developing Countries. USA and Canada: Routledge.

Mutoro, B. A. (1997). Women Working Wonders: Small-Scale Farming and the Role of Women in Vihiga District, Kenya: A Case Study of North Maragoli, Theila. Publishers, Amsterdam.

Mwaura, F., Tungani, J., Sikuku, D., \& Woomer, P. (2012). Acceptability of cereal banks as a marketing intervention among small holder farmers in western Kenya. Outlook on Agriculture, 41(1), 35-40(6).

Nyakaana, Baker, J., \& Edroma, E. (2008). Integrating wildlife in natural resources management for tourism and community livelihoods in Lake Victoria basin: East Africa. African Journal of Environmental Science and Technology, 2(10), 287-295.

Okoboi, G., Muwanika, F. R., Mugisha, X., \& Nyende, M. (2011). Economic and Institutional Efficiency of the National Agricultural Advisory Services' programme: The Case of Iganga District. EPRC Research Series No.76.

Republic of Ghana. (2005). Growth and Poverty Reduction Strategy (GPRS 11) 2006-2009. Government of Ghana.

Republic of Ghana. (2007). Food and Agriculture Sector Development Policy (FADDEP11) Accra. Government of Ghana.

Rogers, E. M. (2003). Diffusion of Innovations (5th ed.). New York: Free Press.

Rondot, P., \& Collin, M. (2001). Agricultural Producer Organizations: their contribution to rural capacity building and Poverty Reduction.

Sabates Wheele, R. (2006). Safety in Small numbers: Local Strategy for Survival and Growth in Romania and the Kygyz Republic.

Sabates Wheeler, R., \& Childress, M. D. (2004). Asset-pooling in uncertain times: implications of small group farming for agricultural restructuring in the Kyrgyz Republic. IDS working paper 239.

Salifu, A., Francesconi, G. N., \& Kolavalli, S. (2010). A Review of Collective Action in Rural Ghana. IFPRI Discussion Paper 00998. 
Towo. (2004). The Gender dimension of rural producers in Tanzania.

Uliwa, P., \& Fisher, D. (2004). Assessment of Tanzania's producer Organizations. Experience and Environment. USAID Economic growth office.

United Nations (UN). (2010). Innovation for Sustainable Development: Local Case Studies from Africa. Kenya: UN Nairobi.

Uganda Bureau of Statistics. (2008). Uganda Census of Agriculture 2008/09: Enumerators Instruction Manual. Kampala, Uganda.

Uganda Bureau of Statistics. (2010). 2009/10 Uganda National Household Survey: Socio-economic report. Kampala, Uganda.

Wooldridge, J. M. (2009). Introductory Econometrics (4th ed.). A Modern Approach. 
Appendix 1. Descriptive statistics of variables used in the model

\begin{tabular}{|c|c|c|c|c|c|c|}
\hline Variable & $\begin{array}{c}\text { Unit of } \\
\text { measurement }\end{array}$ & $\begin{array}{c}\text { No. of } \\
\text { Observations }\end{array}$ & Mean & $\begin{array}{l}\text { Standard } \\
\text { deviation }\end{array}$ & Minimum & Maximum \\
\hline Age & Years & 88471 & 33.99 & 15.278 & 16 & 86 \\
\hline Age squared & Years & 88663 & 1.403 & 1.325 & 0.256 & 8.1 \\
\hline Gender & $\begin{array}{l}\text { Male }=1 \\
\text { Female }=0\end{array}$ & 92485 & 0.498 & 0.500 & 0 & 1 \\
\hline Never married & Yes $=1, \mathrm{No}=0$ & 92485 & 0.323 & 0.468 & 0 & 1 \\
\hline Married & $\mathrm{Yes}=1, \mathrm{No}=0$ & 92485 & 0.562 & 0.496 & 0 & 1 \\
\hline $\begin{array}{l}\text { Widowed and } \\
\text { remarried }\end{array}$ & Yes $=1, \mathrm{No}_{0}=0$ & 92485 & 0.062 & 0.242 & 0 & 1 \\
\hline $\begin{array}{l}\text { Divorced and not } \\
\text { remarried }\end{array}$ & Yes $=1, \mathrm{No}=0$ & 92485 & 0.024 & 0.154 & 0 & 1 \\
\hline Married but separated & Yes $=1, \mathrm{No}=0$ & 92485 & 0.028 & 0.165 & 0 & 1 \\
\hline No education & Yes $=1, \mathrm{No}=0$ & 93760 & 0.191 & 0.393 & 0 & 1 \\
\hline Some primary & Yes $=1, \mathrm{No}=0$ & 88592 & 0.370 & 0.483 & 0 & 1 \\
\hline Completed primary & Yes $=1, \mathrm{No}=0$ & 88592 & 0.180 & 0.384 & 0 & 1 \\
\hline Some secondary & Yes $=1, \mathrm{No}=0$ & 88592 & 0.218 & 0.413 & 0 & 1 \\
\hline A level or higher & Yes $=1, \mathrm{No}=0$ & 88592 & 0.033 & 0.179 & 0 & 1 \\
\hline $\begin{array}{c}\text { Share of children above } \\
17 \text { years }\end{array}$ & Number & 92485 & 0.314 & 0.217 & 0 & 1 \\
\hline Household size & Number & 92485 & 6.630 & 3.438 & 1 & 30 \\
\hline Log of Land & Hectares & 92528 & 0.632 & 0.448 & 0 & 3.40 \\
\hline Local produce market & Kilometres & 92528 & 1.515 & 0.706 & 0 & 6.11 \\
\hline District produce market & Kilometres & 92528 & 2.706 & 0.803 & 0 & 6.63 \\
\hline Local input dealer & Kilometres & 92528 & 1.803 & 0.793 & 0 & 5.74 \\
\hline Extension services & Kilometres & 92528 & 1.972 & 0.701 & 0 & 6.83 \\
\hline Nurseries & Kilometres & 92528 & 2.125 & 0.836 & 0 & 6.69 \\
\hline Feeder roads & Kilometres & 92528 & 0.996 & 0.601 & 0 & 6.22 \\
\hline All year gravel road & Kilometres & 92528 & 1.257 & 0.711 & 0 & 6.40 \\
\hline Crop agriculture & Yes $=1, \mathrm{No}=0$ & 73332 & 0.772 & 0.420 & 0 & 1 \\
\hline Non crop agriculture & Yes $=1, \mathrm{No}=0$ & 73332 & 0.035 & 0.183 & 0 & 1 \\
\hline Trader/Artisan & $\mathrm{Yes}=1, \mathrm{No}=0$ & 73332 & 0.034 & 0.180 & 0 & 1 \\
\hline Paid employment & Yes $=1, \mathrm{No}=0$ & 73332 & 0.061 & 0.240 & 0 & 1 \\
\hline No activity & Yes $=1, \mathrm{No}=0$ & 73332 & 0.031 & 0.175 & 0 & 1 \\
\hline Housework & $\mathrm{Yes}=1, \mathrm{No}=0$ & 73332 & 0.067 & 0.250 & 0 & 1 \\
\hline Kampala & $\mathrm{Yes}=1, \mathrm{No}=0$ & 92485 & 0.006 & 0.076 & 0 & 1 \\
\hline Central 1 & Yes $=1, \mathrm{No}=0$ & 92485 & 0.079 & 0.269 & 0 & 1 \\
\hline Central 2 & Yes $=1, \mathrm{No}=0$ & 92485 & 0.083 & 0.275 & 0 & 1 \\
\hline East Central & $\mathrm{Yes}=1, \mathrm{No}=0$ & 92485 & 0.100 & 0.300 & 0 & 1 \\
\hline Eastern & Yes $=1, \mathrm{No}=0$ & 92485 & 0.212 & 0.408 & 0 & 1 \\
\hline Mid North & Yes $=1, \mathrm{No}=0$ & 92485 & 0.109 & 0.312 & 0 & 1 \\
\hline North East & Yes $=1, \mathrm{No}=0$ & 92485 & 0.042 & 0.201 & 0 & 1 \\
\hline West Nile & Yes $=1, \mathrm{No}=0$ & 92485 & 0.084 & 0.277 & 0 & 1 \\
\hline Mid West & Yes $=1, \mathrm{No}=0$ & 92485 & 0.121 & 0.326 & 0 & 1 \\
\hline South Western & Yes $=1, \mathrm{No}=0$ & 92485 & 0.164 & 0.371 & 0 & 1 \\
\hline
\end{tabular}


Appendix 2. Household membership to farmer groups by characteristics in Uganda

\begin{tabular}{|c|c|c|}
\hline & Proportion \% & $\begin{array}{l}\text { Average number of } \mathrm{HH} \\
\text { members in farmer groups }\end{array}$ \\
\hline \multicolumn{3}{|l|}{ National } \\
\hline Uganda & 16.2 & 1.6 \\
\hline \multicolumn{3}{|l|}{ Household head } \\
\hline Female head & 14.0 & 1.4 \\
\hline Male head & 16.8 & 1.6 \\
\hline \multicolumn{3}{|l|}{ Marital status } \\
\hline Never married & 12.2 & 1.6 \\
\hline Married & 17.9 & 1.6 \\
\hline Div/Sep/Wid & 11.5 & 1.3 \\
\hline No stated & 17.6 & 1.5 \\
\hline \multicolumn{3}{|l|}{ Major activity } \\
\hline Crop Agric & 16.4 & 1.6 \\
\hline Non-crop agric. & 25.3 & 1.7 \\
\hline Trader/artisan & 14.9 & 1.4 \\
\hline Paid employ & 14.9 & 1.4 \\
\hline No activity & 5.9 & 1.6 \\
\hline HH work & 11.3 & 1.3 \\
\hline Not stated & 15.6 & 1.4 \\
\hline \multicolumn{3}{|l|}{ Sub regions } \\
\hline Central & 11.4 & 1.3 \\
\hline Kampala & 11.5 & 1.4 \\
\hline Central 1 & 12.9 & 1.3 \\
\hline Central 2 & 10.0 & 1.3 \\
\hline Eastern: & 15.1 & 1.6 \\
\hline East Central & 11.8 & 1.6 \\
\hline Eastern & 17.1 & 1.7 \\
\hline Northern: & 21.1 & 1.8 \\
\hline Mid-North & 23.5 & 1.7 \\
\hline North East & 24.4 & 2.4 \\
\hline West Nile & 16.1 & 1.6 \\
\hline Western: & 17.2 & 1.5 \\
\hline Mid-West & 14.7 & 1.5 \\
\hline South-Western & 19.4 & 1.6 \\
\hline
\end{tabular}


Appendix 3. Comparing linear probability, Probit and Logit model estimates

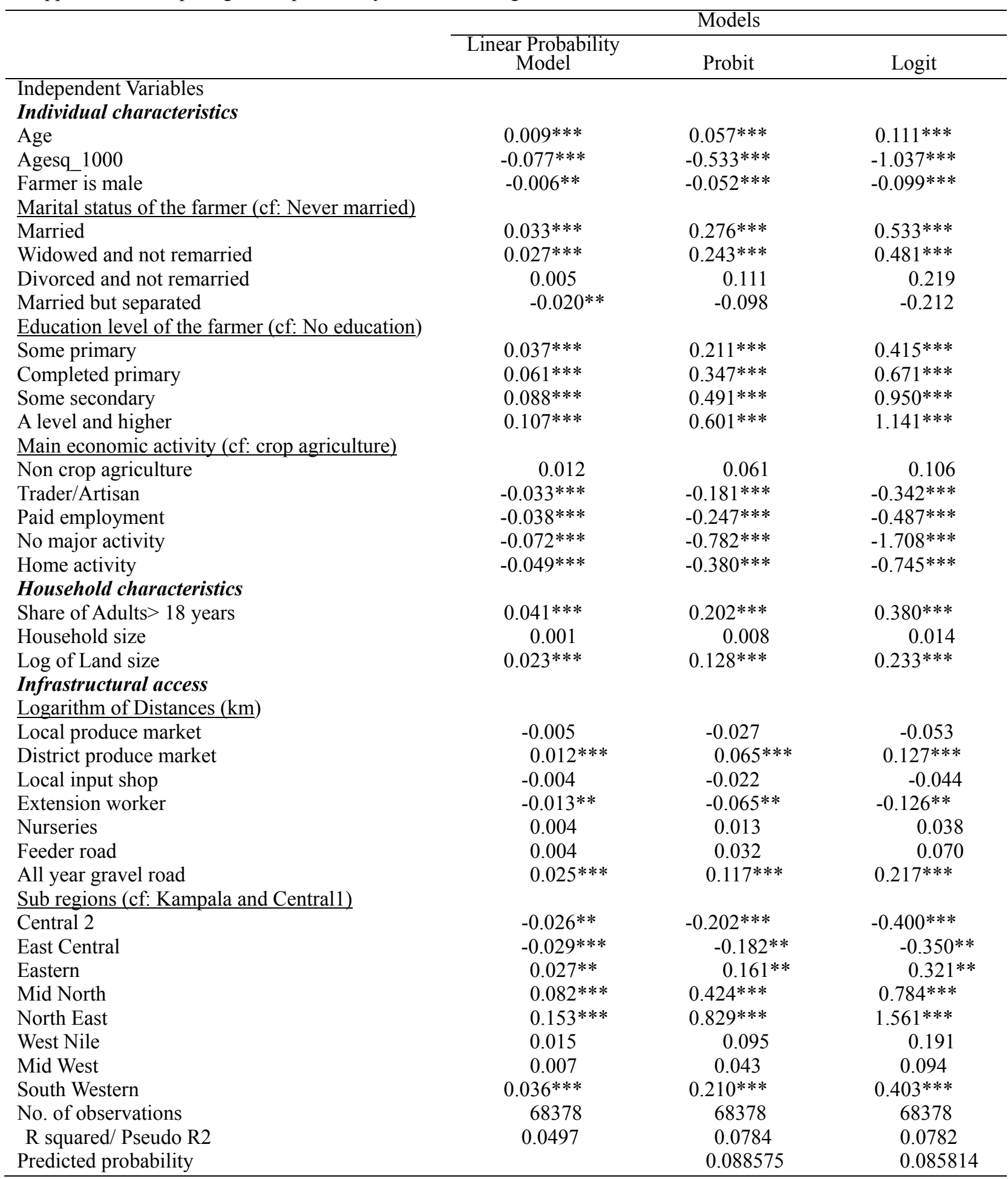

Source: Authors calculation based on UCA 2008/09, ${ }^{* * *},{ }^{* *}$, and * indicatestatistical significance at 1, 5 and $10 \%$ level; the values reported are coefficients.

\section{Note}

Note 1. This paper builds on the initial poster by the Adong et al., 2012 in preparation for presentation at the International Association of Agriculture Economist 2012 Triennial Conference, Foz do Iguaçu, Brazil 18- 24 August 2012, http://ageconsearch.umn.edu/bitstream/126774/2/AdongWCover.pdf 